\title{
Impact of Urbanization on Public Health in Kathmandu Valley, Nepal- A Review
}

\author{
Peng Jian Dong* and Trishna Karmacharya \\ School of Urban Design, Wuhan University, China
}

Submission: May 09, 2018; Published: May 17, 2018

*Corresponding author: Peng Jian Dong, School of Urban Design, Wuhan University, Wuhan, Hubei 430072, China, Tel: +86 18007133408; E-mail: 99339101@qq.com

\begin{abstract}
Urbanization in an uncontrolled and unorganized manner with no policy of migration creates a negative impact on the environment and public well-being of Kathmandu Valley; the biggest urban center in Nepal. Air pollution and Water pollution are one of the major health threats to a citizen of the valley. Emissions from vehicles being more accountable for air pollution. Traffic, including emissions and dust associated with traffic, is an utmost potential threat; winter months being most helpless. Particulate matters are major pollutants responsible for respiratory infection and other health-related problems. The scarcity of drinking water supply, highly dependent on contaminated groundwater sources, particularly with coliform bacteria and other pollutants along with toxic metals causing various health problems. Human activities like improper disposal of municipal, industrial effluents, haphazard application of fertilizer, occasionally broken waste treatment plant are main factor deteriorating water quality. With data extracted from various studies in national and international journals, government and non-government organizations reports, this review discusses pollution impact of urbanization in Kathmandu Valley with a major source of pollution and its consequent health problems and attempt to provide some recommendations to cope such problem.
\end{abstract}

Keywords: Urbanization; Air pollution; Water pollution; Health impact; Kathmandu Valley

Abbreviations: LCD: Less Developing Country; UNISDR: United Nations Office for Disaster Risk Reduction; COPD: Chronic Obstructive Pulmonary Disease; ENPHO: Environmental and Public Health Organization; MOPE: Ministry of Population Ns Environment; MWSP: Melamchi Water Supply Project; EPI: Environment preference Index; TSP: Total Suspended Particles; NEFEJ: Nepal Forum of Environmental Journalists; NAAQS: National Ambient Air Quality Standard; NEFEJ: Nepal Forum of Environment Journalists; ARI: Acute Respiratory Infection; EBD: Environmental Burden of Disease; VSBK: Vertical Shaft Brick Kilns; SDAN: Sustainable Development Agenda for Nepal; NVMES: Nepal Vehicle Mass Emission Standard; KUKL: Kathmandu Upatyaka Khanepani Ltd; MLD: Millions Liters Per Day; GRAM: Groundwater Risk Assessment Model; EIA: Environment Impact Assessment; NDWQS: National Drinking Water Quality Standards; BRT: Bus Rapid Transit

\section{Introduction}

Urbanization has been taken as a process of the country's economic development and dissimulate as an enhancement for various possibilities for human being. Theories and policies are developed to offer opportunities for vital infrastructures and services like housing, education, employment, social cohesion and the expectation of a better life and better health, but in an actual situation, these opportunities may not be assured as expected for better living conditions [1]. In 1950, 30 percent world population was urban. In 2014, it has increased to 54 percent and by 2050, 66 percent is estimated to be urban [2]. In the foreseeable future, the urban population will be higher in less developed countries in the world, the whose accumulated population is projected to increase from 2.38 billion in 2007 to 5.3 billion in 2050 [3].

Inseparable from global phenomena, Nepal being less developed, the low-income country has also been experiencing urban population growth since 1970 and in the last few decades, rapid resident's growth made Nepal one of the highest urbanization rates in Asia and the Pacific [4]. The urban center development process in Nepal starts with the re-establishment of multi-party democracy in 1990. Adoption of the liberal market-led economic policy opened ways for investment in businesses-financial markets and industries in the country [5]. Speedy populaces rise as citizens relocated for the livelihood, and rural-urban migration has been a prominent factor in rapid population growth because of urban transition in LCDs. The gradual addition of unemployed vagrants in urban zones in LCDs is demonstrative less of urban dynamism than solid repulsive powers working rustic ranges [6]. Migrants respond primarily to economic incentives, higher in underdeveloped-developing countries, the wage difference in the city and countryside made strong impediments to relocate [7]. In Nepal, better economic opportunities may be a major pulled factor for rural-urban movement $[6,8]$. 
World-o-meters reports, in 2018, 19.6 percentage of the population in Nepal is urban [9], 2.9 percentage recorded in 1952-54 [10], between 1952/54 and 2018 total urban population increased nearly by sevenfold. Natural growth, migration, assignment of additional metropolitan towns and extension of cities, integrating with rustic regions can be the reason behind the high growth rate [11]. In recent times, relocation of the populace is one of the vital variables for quick growth of expansive urban range, in 2011, 33.5 percentage migrated rural to urban [10]. Only 10 urban areas were recognized at the time of the first scientific population census in 1952/54 (population census completed in 2 years from 1952 to 1954), in most recent population census (2011), the number of urban has reached to 130 [10]. Ministry of Population and Environment [10] in Nepal categorise urban area having a minimum population of 20,000 and should have electricity, road, drinking water and telecommunication facilities.

\section{The Kathmandu Valley}

The Kathmandu Valley of Nepal located in the central part hill region occupies about 656 kilometers square (Figure 1). The central part of the valley is flat land at an elevation of 1300-1400 meters from the mean sea level. The tectonic basin of Kathmandu valley is surrounded by mountains rising above 2000 meters high.

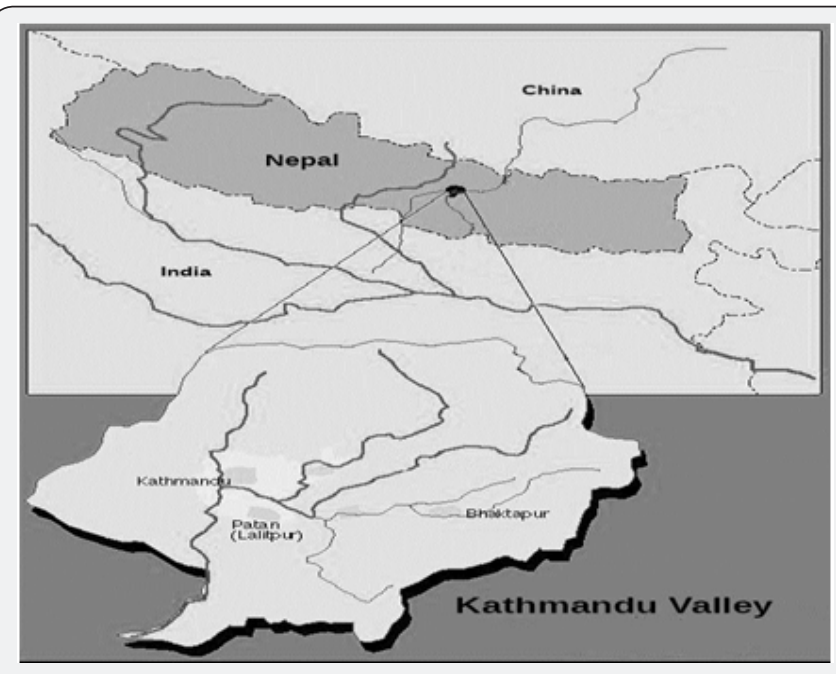

Figure 1: Location of Kathmandu Valley.

The Kathmandu Valley is the most developed urban center in Nepal. The valley has the large metropolis Kathmandu, which is capital as well, third big city Lalitpur and other three municipal towns; Bhaktapur, Kritipur and Madhyapur Thimi. The urban center development starts with the re-establishment of multiparty democracy in 1990. Adoption of the liberal market-led economic policy opened ways for investment in businessfinancial markets and industries in the country [5]. Cities of valley have its social-cultural importance from the date back the $7^{\text {th }}$ century; the Lichhavi era and in 1768 Kathmandu city declared as the capital of newly unified Nepal, main political and the administrative center of the country [5]. This begins human migration from several parts of the nation to the valley. Further, rich agricultural resource base with productive soil and water supply, and long distance trading activity were fundamental factors for initially urban growth in the valley, which later provided revenue for a strong economic base; flourish smallscale production of textiles, metalwork and even exports in the foreign trade [11]. Migration enlarged in recent past decades as an incredible revolution in physical development took place in the starting of the twentieth century. This involves a transformation in transport infrastructure, the construction of extravagant palaces, and migrants were attracted to the roadside resident; to get advantage from the road. Another factor, adjustment to political factor in the 1960s expanded government workplaces, growth in international aid and development of organized road driven a further influx of migrations into the valley [12].

Opportunities for economic development, highwaystransportation, and more social-cultural prominence this leads to citizen's overconcentration, resulting in foster migration to an urban center [13]. The valley's urban population is 2.5 million, which is more than one-third of the countries total urban population [9] with an annual growth rate of 4 percent (Table 1) [10]. The Kathmandu Valley is the first region to face the prodigious challenges of rapid urbanization at a metropolitan scale $[8,14]$.

Table 1: Growth of Population of the Kathmandu Valley Urban Region by Census Year Source $[10,14]$.

\begin{tabular}{|c|c|c|c|}
\hline Year & $\begin{array}{c}\text { Total } \\
\text { Population }\end{array}$ & $\begin{array}{c}\text { Population } \\
\text { Growth }\end{array}$ & Growth Rate \\
\hline 1981 & 770,389 & --- & --- \\
\hline 1991 & $1,105,379$ & 334,990 & $3.70 \%$ \\
\hline 2001 & $1,645,091$ & 539,721 & $4.10 \%$ \\
\hline 2011 & $2,517,023$ & 871,932 & $74.2 \%$ \\
\hline
\end{tabular}

Urbanization leads towards economic growth and urban centers are the engines of the global economy [15]. Skilled and qualified individual migration helped city grown and made Kathmandu the most competitive city in the country. According to the population census of $2001,44 \%$ of the total population in the valley is economically active [16]. Development in Industries, tourism sector, real estate, administration, trade, health, and education sector provided a more significant number of jobs, it is believed to be a major bottleneck in Nepalese economic transformation [17]. Eventually, swift progress in information technology and the emergence of a global market, the per capita income of Kathmandu Valley has increased by 407 percent from 1996 to 2011 [18].

Incongruously, unable to organize and uncontrolled migrate populace growth associated with settlement and cultivation on the marginal land, destruction of essential wetland or forest area encourages soil erosion, landslides, and desertification [19] which badly affects the country's economy especially in a low- 
income country like Nepal [10]. UNISDR reported Nepal had an economic loss of 12.9 percent because of a landslide in 24 years (1990-2014) [20].

Moreover, people living in the urban region of developing countries are dealing with poverty, malnutrition, inadequate or no housing, poor quality or a severe lack of drinking water which lead to unhealthy living [21]. Despite numerous advantages of urbanization of the country and its citizen, we cannot neglect its enormous negative effects, which generate a wide - range of problems in the environment and human wellbeing. International studies have shown there are serious health risks associated with urbanization [21,22] and Nepal might not be an exception. Currently, different researchers carried out in Kathmandu Valley shows pollution, health threat is increasing exceedingly through the air [23], water and land [8]. In this study, the increment in pollution level due to urban growth in Kathmandu Valley and their impact on public health is presented and attempt to put forward possible alternatives.

\section{Urban Health Issues: Environmental Implications of the Valley's Urban Growth}

Rapid population growth and urbanization help to promote the economic development of citizens and country. Urbanization itself is harmless, but the uncontrolled and haphazard growth of urban settlements beyond capacity, invites many environmental problems, this is the case Kathmandu Valley is facing [11]. The government of Nepal prioritizes ten broad areas as major environmental health problems in Nepal [24]. This study addresses two major environmental problems currently faced by Kathmandu Valley. a) Air pollution

b) Water Pollution

Air Pollution: National Institute of Environmental Health Science has defined air pollution as "the mixture of natural and man-made substances in the air we breathe. International experts as well as WHO have recognized that fine particles are the most vulnerable to air pollutants. The minute the particles in the air, it's potential to cause health problem upswings [2528]. Death attributed to air pollution has risen steadily over the past decade [29]. In 2012, poor air quality was responsible for 3 million premature deaths globally; $87 \%$ are from low-middle income countries due to the exposure to $\mathrm{PM}_{10}$ (fine particulate matter 10 microns or smaller) and $\mathrm{PM}_{2.5}$ (fine particulate matter 2.5 microns or smaller).

In Kathmandu valley, over the last 2 decades, registration of vehicles in Kathmandu valley has peaked from 53,704 to 570,143 almost tenfold (Figure 2) [30]. This tremendous rise of motorized transport has drastically expanded the rate of mishaps and air pollution. Heavier duty diesel vehicles; exhaust 90 percent of less than 1- micron particles [31], a large number of old and un-maintained engines further exacerbate air quality in the valley [31]. The increment of vehicles may be because of the road is the only medium of transportation (ADB and CAI-Asia Center 2006) and automobiles are the only way, provision of foot paths-bicycle tracks are very poor even within short distance of destination. Solid fuels for domestic energy contribute indoor air pollution [32-34]. Road dust, low-grade coal used in over 110 brick kilns and biomass/garbage burning are other sources of air pollution in Kathmandu Valley [35].

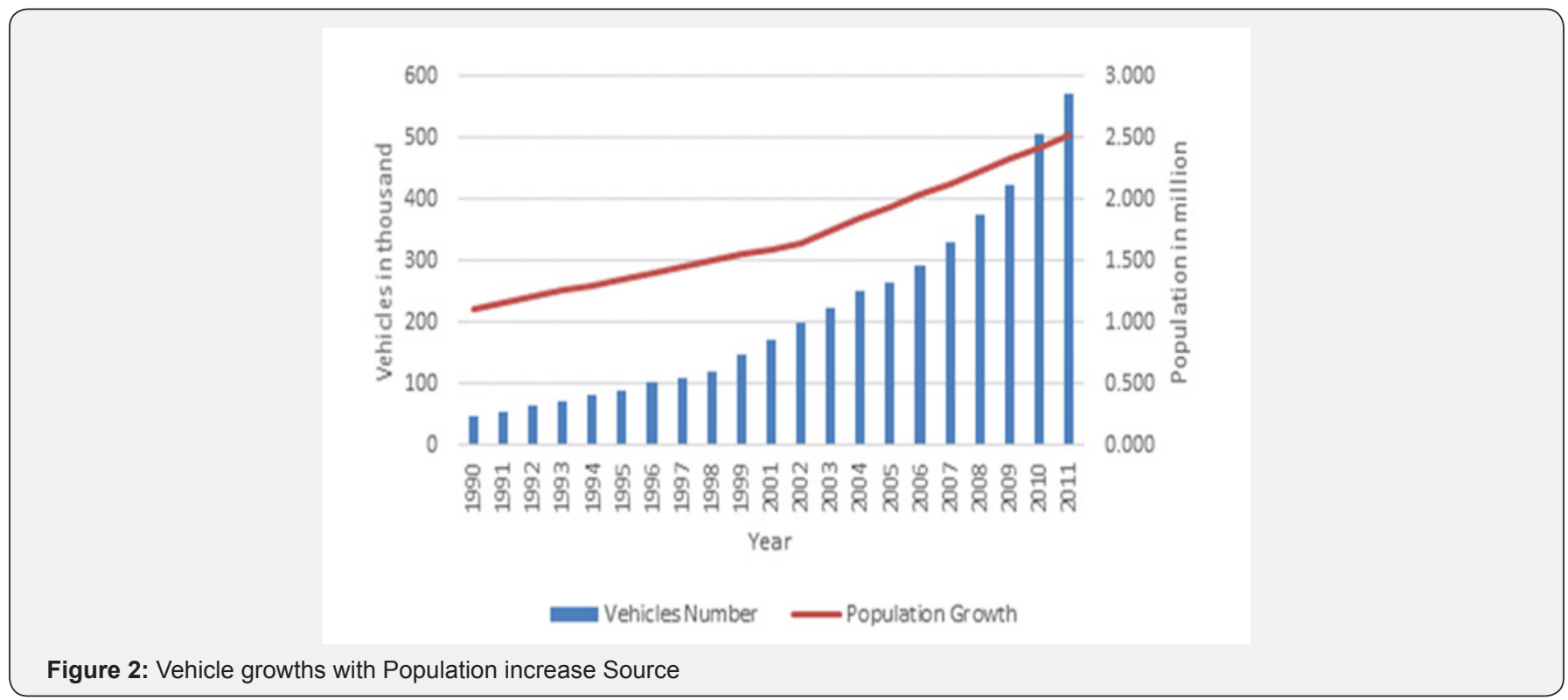

In response to the urbanization and multiplied automobiles, Nepal government initiated road expansion project throughout the valley in 2011 to reduce traffic congestion [36]. This positive step of the Government for the betterment of citizen and country, on the contrary, too poorly managed road expansion, political and local obstruction, in 5 years, only 25 percent work done, 7 percent of them are blacktopped $[37,38]$, contributing road dust particles in the air and unorganized slow processed 


\section{Juniper Online Journal of Public Health}

road expansion is still ongoing [39]. Withal, increased demand for housing and construction since the year 2000, brick industry in the valley has grown by $200 \%$ [40] and the use of cheaper fuels such as coal, firewood, and burning of biomass, sawdust, garbage etc. has helped the emission of high amount of harmful smoke $[35,40]$. Together with automobile emissions and re-suspended road dust, brick industry's dust particles are responsible for reducing air quality substantially causing various health problems like COPD, asthma, bronchitis, silicosis, and other pulmonary complications [41].

Comparing data collected in November 1992 and November 2002 by the ENPHO and MOPE respectively at Putali Sadak; a highly dense and busy commercial area, indicate that over a 10 year period there has been a threefold increase in PM10 levels [31]. The most recent study by government to analyze ambient air pollution in the Kathmandu Valley for a year shows pollutant $\mathrm{PM}_{2.5}$ and $\mathrm{NO}_{2}$ exceeds NAAQS for more than half of the year [42] and several periodic studies executed in various parts of Kathmandu valley $[30,31,40,23,24,42-46]$ likewise indicated that Kathmandu Valley's air is polluted with harmful level of $\mathrm{PM}_{2.5}$ and $\mathrm{NO}_{2}$. In the winter months (November-February), the pollutants increase by 3-4 times than NAAQS and gradual shrinkage during monsoon season [24,42]. In the dry season when power outage generally at its peak, most of the industrial and commercial sectors use diesel generators as an alternative source of electricity. The study shows that around $66.5 \%$ of total diesel was consumed only in Kathmandu Valley in 2012-2013; mostly used for running diesel-powered generators, has emitted nearly 400 tons of $\mathrm{PM}_{10}$ [42]. Moreover, the operation of brick factories mostly during the dry season (December-May) [41], are the reasons for seasonal pollutant variation.

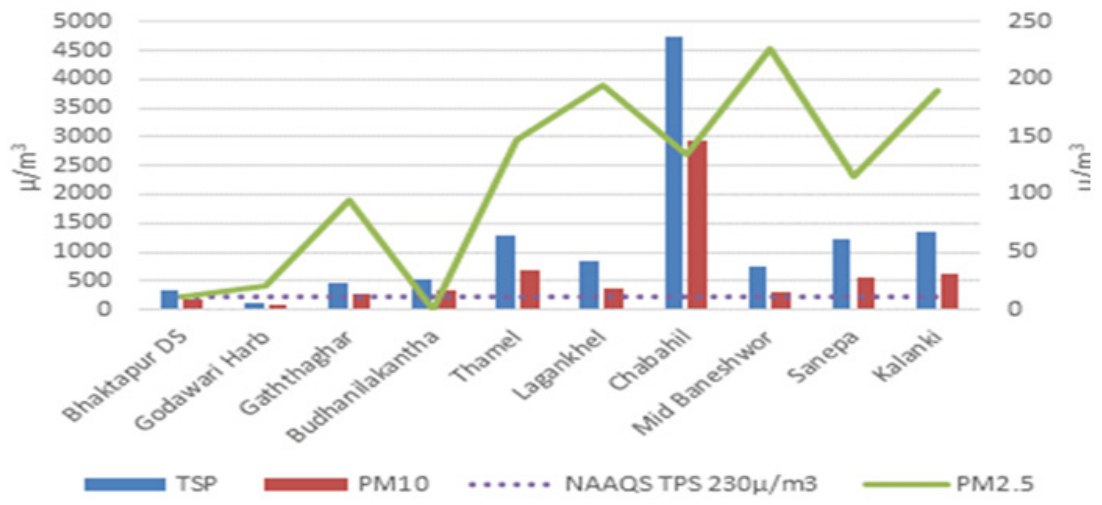

Figure 3: One day monitoring 24 hours average TPS, PM10 \&PM2.5 in Kathmandu valley, May 2017 Source.

At present, people of Kathmandu Valley suffer much more, particularly from road expansion project and MWSP; excavation of paved road for laying drinking water pipe underneath the road, which is still in halfway and its continued suspension of dust particles in the movement of vehicles. The condition has lowered to the visibility of a nearby object [39]. Recent, EPI 2018 has stated Nepal in bottom five worst on air quality among 180 countries [31]. To understand the level of TSP together with
$\mathrm{PM}_{10}$ and $\mathrm{PM}_{2.5}$ in a dry day [14] carried out 24 hours monitoring on the roadside of a residential area in 10 different location of the valley (Figure 3).

Measurements of TSP and PM10 the highest recorded concentration at Chabahil whereas, $\mathrm{PM}_{2.5}$ maximum at $\mathrm{Mid}$ Baneshwor. Godawari Harb alone seems to below NAAQS of TPS $230 \mu / \mathrm{m}^{3}$, PM10 $120 \mu / \mathrm{m}^{3}, \mathrm{PM}_{2.5} 40 \mu / \mathrm{m}^{3}$.

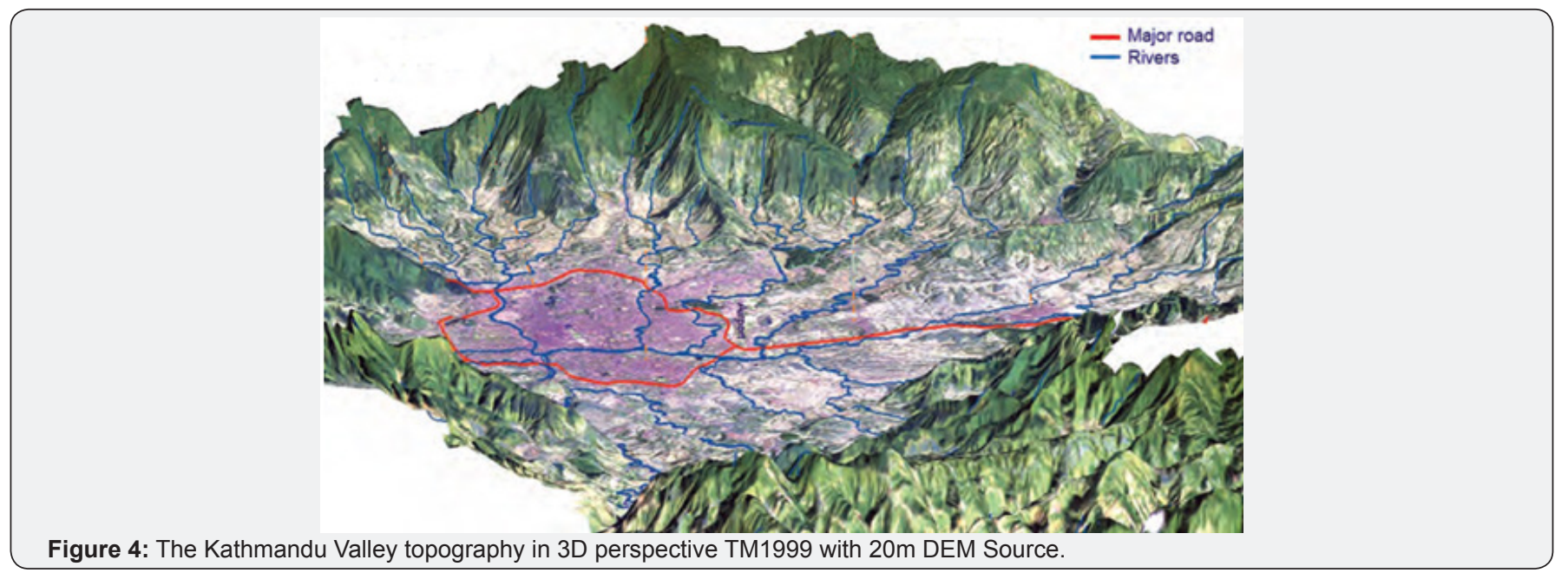


These high emissions of pollutant created by human activities and the unique topographic feature of the valley particularly vulnerable to air pollution. The Kathmandu Valley is located in middle section of Himalayan range and is surrounded by Phulchowki Hill (3132m) in South West, Shivapuri (2713m) in North, Champa Devi (2400m) in South West and Nagarjuna $(2100 \mathrm{~m})$ in West Hills, forming bowl-like shaped structure [47]. According to Nepal NEFEJ, The mountains surrounding Kathmandu Valley blocks airflow. The increasing temperature lately is causing warm air to rise and cold air to sink in the Valley, and the same warm air then cools and sinks again, causing air pollution to stay locked in (Figure 4) [48].

\section{a) Health Effects of Air Pollution}

Over the lifespan, humans are in contact with various concentrations of pollutants and it is challenging to evaluate the quality of per-mature decrease or morbidity due to air pollution [49]. Generally, international and national ambient air quality standard provides a threshold of air pollutant, exceeding that consider harmful to human health [50]. Inhalation is the most common route for pollutants to enter the human body damaging respiratory system and cause other respiratory diseases. In Kathmandu Valley, coughing, sore throat, runny nose, sneezing, headache, fever which come under mild respiratory disease are the day-to-day thing to which person does not visit hospital unless becoming severe. Nepal Health Research Council [42] conducted a study in the hospital to analysis respiratory disorders with ambient air pollution $\left(\mathrm{PM}_{25}\right)$. A year-long continuous monitoring of $\mathrm{PM}_{2.5}$ concentration and analysis of respiratory health effects in 11,300 inpatient records in the fiscal year 2014/2015 from thirteen major hospitals of Kathmandu Valley shows that there is a steady downturn in the seasonal trend from spring to winter for total cases of respiratory hospitalization. This indicates that $\mathrm{PM}_{2.5}$ is positively correlated with records inpatient in hospitals. Among the respiratory diseases, COPD, Pneumonia and ARI are the leading causes (Figure 5) and (Table 2). There is limited health-related research associated with ambient air pollution in Nepal including Kathmandu, more studies of health burdens can further abet to develop policies important for human well-being [44,51-57].

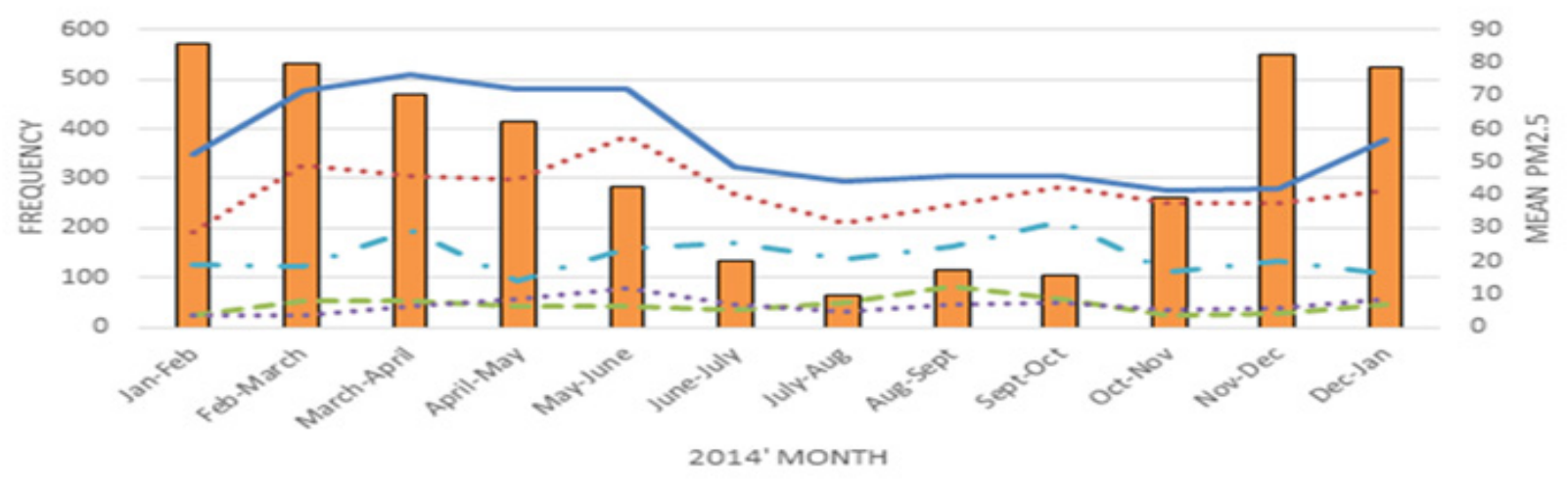

ऍPM2.5 -COPD .... Pneumonia - - - Asthma .... Bronchistis - . ARI

Figure 5: Monthly variation of PM2.5 in Kathmandu Valley and Monthlyvariation of respirathospitalizations with pollution Source

Table 2: Describes the Impact of air Pollution on Health.

\begin{tabular}{|c|c|}
\hline Author and Year & Key Findings \\
\hline \multirow[t]{2}{*}{ World Bank, [51] } & - Estimate impacts on mortality and morbidity due to PM10. \\
\hline & $\begin{array}{l}\text { - Excess mortality } 84 \text {, chronic bronchitis } 506 \text {, bronchitis in children } 4,847 \text {, asthma attacks } 18,863 \text {, respiratory symptom } \\
\text { days } 1,512,689 \text {, respiratory hospital admissions } 99 .\end{array}$ \\
\hline \multirow[t]{3}{*}{ CWIN, [52] } & $\begin{array}{l}\text {-Heath examines including chest } \mathrm{x} \text {-ray and a blood test of children }(65 \%<14 \text { years) working as money collector in tempos } \\
\text { ( } 3 \text { wheeled vehicles). }\end{array}$ \\
\hline & $\begin{array}{l}\text {-They work } 14 \text { hours a day standing back of the tempos just above exhaust pipe. During working hour they breathe } 4,116 \\
\mu \mathrm{g}, 1,225 \mu \mathrm{g}, 17,689 \mu \mathrm{g} \text { of PM10, NO2 and TSP respectively. }\end{array}$ \\
\hline & $\begin{array}{c}\text {-Heath examine result, eye problem (84\%); chest pain (82\%); headaches and nausea (58\%); fever (53\%); } 66 \% \text { cough and } \\
\text { cold (66\%); difficulty in breathing ( } 45 \%) \text {; pneumonia; tuberculosis; bronchitis and chest problems (29\%); anemia (18\%) } \\
\text { and skin problems (21\%). }\end{array}$ \\
\hline NESS, [53] & $\begin{array}{l}\text {-Study for NHRC using threshold concentration of PM10 }\left(40 \mu \mathrm{g} / \mathrm{m}^{3}\right)-92 \text { children less than } 5 \text { years die per year and approx. } \\
665,000 \text { cases of respiratory complication. }\end{array}$ \\
\hline $\begin{array}{l}\text { ABD \& CAI-Asia } \\
\text { Center [54] }\end{array}$ & -Survey impact of air pollution on 105 traffic police questionnaire survey- 90 traffic police \\
\hline
\end{tabular}




\section{Juniper Online Journal of Public Health}

\begin{tabular}{|c|c|}
\hline & $\begin{array}{l}\text { unstructured interview- } 20 \text { traffic police field observations and medical tests (oxyhemoglobin } \\
\text { and flow meter test)- } 5 \text { traffic police }\end{array}$ \\
\hline & $\begin{array}{l}\text {-Impact on nervous system ranged between } 58 \%-74 \% \text {, including dizziness, depression, headaches, forgetfulness, } \\
\text { irritation, lack of concentration etc. }\end{array}$ \\
\hline & $\begin{array}{c}\text {-Impact on respiratory system ranged between } 26 \%-87 \% \text {, including severe cold, asthma, cough, sneezing, nose irritation, } \\
\text { and low resistance to influenza. }\end{array}$ \\
\hline & $\begin{array}{l}\text {-Impact on cardiovascular system ranged from 39\%-63\%, including rapid heartbeat, chest pain, high blood pressure, and } \\
\text { anemia. }\end{array}$ \\
\hline & -Other impacts included reddening of eyes, watery and burning sensation in the eyes, and reduction in vision. \\
\hline \multirow[t]{3}{*}{ CEN \& ENPHO, [31] } & -Analyzed hospital records of COPD patients and control patients. \\
\hline & $\begin{array}{l}\text {-Numbers of COPD admitted to hospital and percentage of total medical COPD patients has increased significantly in the } \\
\text { last } 10 \text { years. }\end{array}$ \\
\hline & -COPD is 1.96 times higher for Kathmandu Valley residents compared with outside valley resident. \\
\hline \multirow[t]{2}{*}{ NHRC \& WHO, [55] } & $\begin{array}{c}\text {-The study shows person exposed to solid bio-fuel smoke show } 16.8 \% \text { higher prevalence of respiratory abnormalities as } \\
\text { compared to clean fuel users. }\end{array}$ \\
\hline & -ARI prevalence is found to be $16.8 \%$ as compared to processed fuel which is $7 \%$. \\
\hline NHRC \& WHO, [56] & $\begin{array}{c}\text {-EBD due to PM10 concentration in Kathmandu Valley against the baseline concentration of } 10 \mu \mathrm{g} / \mathrm{m}^{3} \text { was } 1,926 \text { cases of } \\
\text { premature mortality per year. }\end{array}$ \\
\hline
\end{tabular}

\section{b) Government Policies on Air Quality Control}

Several act, policies, rule, and regulations have been introduced by Government to regulate air pollution. However, present condition express the implementation of policies have not been in practice (Table 3). This legislation was aimed to reduce air pollution and improving air quality to provide people's rights to clean environment. Government policies were revised and approved now and then; however, there is lack of an elaborate systematic plan of action for their implementation. Monitoring quality of the air and discharge from the vehicles are

Table 3: List of Important Government Policies to Control air Quality Source [24,47].

\begin{tabular}{|c|c|}
\hline Act and Regulation & Areas Addressed \\
\hline National conservation Strategy 1988 & $\begin{array}{l}\text {-The first strategy to an emphasis on air pollution policies and suggest } \\
\text { standardizing its quality. }\end{array}$ \\
\hline Transportation management Act 1992 and Regulation 1997 & -The condition of the vehicle; high mileage and smoke discharge examine policy. \\
\hline \multirow[t]{2}{*}{ Environment protection Act and Rules 1997} & -Industries and all which produce pollution should undergo EIA procedure. \\
\hline & $\begin{array}{l}\text {-Introduced NAAQS in } 2003 \text { and update version till 2012, to minimize Air } \\
\text { pollution through control measure. }\end{array}$ \\
\hline Vehicle and emission examination & -Green sticker system applied 1999. \\
\hline \multirow[t]{2}{*}{ Prohibition on heavy polluting vehicles } & $\begin{array}{l}\text {-The ban on heavy polluting three wheelers diesel vehicle, import of new two- } \\
\text { stroke and second-hand vehicles in } 1999 .\end{array}$ \\
\hline & -Introduce electric public transportation. \\
\hline National Transport Policy 2002 & -To encourage zero-emission vehicles like solar and electric vehicle. \\
\hline $\begin{array}{l}\text { Industrial Development Perspective Plan } 2002 \text { (update in } \\
\text { 2004) }\end{array}$ & -Emphasis to clean production. \\
\hline $\begin{array}{l}\text { Prohibition on heavily polluting movable brick trench kiln } \\
\qquad 2003\end{array}$ & -The old polluting Brick kiln was barred and introduce Fixed Chimney and VSBK. \\
\hline \multirow[t]{2}{*}{ SDAN 2003} & -Change Petroleum Vehicle to zero-emission vehicles and clean energy industry. \\
\hline & $\begin{array}{c}\text {-Improving indoor air pollution by encouraging cleaner stove technology for } \\
\text { cooking purpose. }\end{array}$ \\
\hline
\end{tabular}

limited in documentation and not regularly published. If Euro III emission can be standardized, $44 \%$ of toxic air pollutant is possible to reduce from considered vehicles [58]. If, $\mathrm{PM}_{2.5}$ and $\mathrm{PM}_{10}$ level can be maintained to NAAQS standard $\left(40 \mu / \mathrm{m}^{3}\right)$ and WHO standard $\left(40 \mu / \mathrm{m}^{3}\right)$ respectively then thousand-fold cases of mortality and diseases like acute bronchitis in children, chronic bronchitis, asthma attacks and other respiratory related problems can be avoided [31]. Nevertheless, deduction of threewheeler diesel public vehicles in 1999, 20 years used old cabs in 2004 and initiating Public Electric Vehicles were some success stories, contributed to reducing further air pollution [24,59]. 


\begin{tabular}{|c|c|}
\hline Interim constitution 2007 & -Guaranteed to provide people's right to a clean environment. \\
\hline NVMES 2000 updated version 2012 & -EURO III emission standard required to import vehicle except for heavy \\
equipment vehicles.
\end{tabular}

Water pollution: Nepal has been facing excess challenges regarding quality as well as the availability of drinking water [60]. According to KUKL; officially authorized the water supplying agency, with an increase in population from 1.64 million in 2001 to 2.42 million in 2011 [60] in Kathmandu Valley, demand for drinking water growing at the rate of nearly 5 percent annually [61]. In 2014/15, average daily demand for drinking water was $375,000 \mathrm{~m}^{3}$ per day but KUKL was only able to supply around $151,000 \mathrm{~m}^{3}$ per day, which is forty percent of its total demand [61]. The remaining population is forced to depend upon supplies from private vendors, bottled water and groundwater sources like tube wells, dug wells, shallow-deep aquifer and stone spouts.

The limited surface water resources, insufficient supply from KUKL and high demand of water has increased the use of groundwater resources [60,61]. Groundwater resources natural recharge also has been affected by the rapid growth of the urban area. The significant variation in land use and land cover decrease recharge capacity of groundwater; the urban builtup area increased by $412 \%$ and agriculture area cutback by $32 \%$ from 1989 to 2016 [62]. And again, water extraction from groundwater as an easy alternative; low cost and accessibility, consequently residence, large-small companies, hotels-housing heavily rely on groundwater resources [63]. According to Snowy Mountains Engineering Corporation, the upper limit of groundwater extraction should be anent 40.1 MLD but extraction levels were already higher in 1989 [64]. Nepal Health Research Council reports 50 percent pulse population are surviving in it [24], this figure shows people are highly dependent on groundwater sources for their daily water needs and this gives major concern in its quality.

Understanding the importance of groundwater for people of Kathmandu Valley, International forums, government agencies, and private sectors have been examining the quality of water. Different studies reported that management system of solid waste and wastewater are a major cause of groundwater pollution in Kathmandu Valley [60,63]. Discharge of sewers, wastewater from domestic and industrial in the river without filtration [24], several leakages from sewage pipes, septic reservoirs and landfill sites, occasionally failing wastewater treatment plants [24] and ammonium-based fertilizer use in agricultural raised the level of pollutant [63]. The study of the risk of Groundwater vulnerability to pollution [63] using GIS-based DRASTIC model and GRAM has showed that $50 \%$ of the groundwater basin area in the valley is susceptible to groundwater pollution and $87 \%$ of the groundwater basin is at moderate residual risk to groundwater pollution. Examination of quality of groundwater under physical, chemical and microbiological parameters has found that iron, total coliform bacteria, electrical conductivity, and turbidity were above WHO recommendation guidelines for drinking water [65]. Similarly, water sample inspected by [60] from over 100 sources in Kathmandu Valley results in the presence of total coliform and Escherichia coli bacteria at $94 \%$ and $74 \%$ respectively and microbiological analysis also identify Escherichia coli as problematic in sample collected from 132 sources [66]. This being scenario of the water quality, it cannot be positive towards the health of the people.

\section{a) Health Effects of Water Pollution}

Water pollution is one of the major causes of illness on public health in Kathmandu Valley. Bad sanitation and contaminated water arising from human activities create serious health effects. Waterborne diseases by quantity are unclear because of lack of maintenance of records at hospitals. According to a government report, waterborne diseases reported as $3^{\text {rd }}$ inpatient morbidity admitted in hospitals [67]. Bacteriological contamination has been regarded as the most potential problem [67] which contribute to water-borne diseases like diarrhea, cholera, hepatitis [24] nausea, gastroenteritis, and typhoid [60]. More studies in diarrheal disease also indicate its vulnerability in Kathmandu Valley $[68,69]$. Ministry of Health and population also reported $30 \%$ diarrhea patient recorded among total cases recorded in Kathmandu Valley [70]. NHRC report, etiology of diarrhea investigated in 181 patients at Teku hospital has stated that the bacterial pathogens were isolated among 33\% of the patients and are considered high particularly among children below the age of five. Typhoid and paratyphoid fevers, unspecified jaundice, non-infective gastroenteritis, and colitis are other leading waterborne diseases [67].

Heavy metals in groundwater and surface water are increasing, maybe the practice of waste disposing of on the banks of rivers or buried not considering its adverse impact on groundwater [71]. High concentration of arsenic, iron, manganese is reported that the other heavy metal like Zinc, Cadmium, Barium, Lead $[60,72,73]$. Many of these metals are considered essential for human health, but on the excess amount, it causes pollution and become toxic to human health [74]. These metals reduce the production of red and white blood cells lowering energy levels and damage the blood vessels and eventually slowing the functioning of important organs like brain, lungs, kidney, and liver [74-76]. With long-term exposure, physical, muscular and neurological deterioration can lead to Paralysis, Parkinson's disease, Alzheimer's disease and Muscular Dystrophy. 


\section{Juniper Online Journal of Public Health}

\section{b) Government Policies on Water Pollution Control}

Recognizing problem-related to water quality several legislative schedules to improve and to protect urban water quality (Table 4).This legislation is aimed at safe drinking water to general public and to prevent water source from deterioration, however, we cannot deny present condition of water source and mismanagement of solid waste and wastewater.

Table 4: List of Important Government Policies to Control Water Quality Source [76].

\begin{tabular}{|c|c|}
\hline Act and Regulation & Areas Addressed \\
\hline Nepal Water Supply Corporation Act 1989 & $\begin{array}{l}\text {-Establish autonomous government controlled corporation as Nepal } \\
\text { water supply corporation responsible for the supply of drinking water }\end{array}$ \\
\hline \multirow[t]{2}{*}{ The Solid Waste Act 1989} & -Control the adverse impact on caused by solid waste pollution \\
\hline & $\begin{array}{l}\text {-Prohibit throwing, leaving or dumping gas or liquid of any kind in other } \\
\text { than containers }\end{array}$ \\
\hline \multirow[t]{2}{*}{ The Water Resource Act 1992} & $\begin{array}{l}\text {-The umbrella Act governing water resources management, provisions } \\
\text { for the maintaining and control of water resources. }\end{array}$ \\
\hline & -Water pollution penalty up to NRs.5000 \\
\hline Environment Protection Regulation 1997 & $\begin{array}{l}\text {-Provision of pollution control certificate to control water pollution from } \\
\text { industrial }\end{array}$ \\
\hline National Water Supply Sector 1998 & $\begin{array}{l}\text {-The policy set the target of providing safe, convenient and adequate } \\
\text { water supply by the year } 2002\end{array}$ \\
\hline \multirow[t]{3}{*}{ Drinking Water Regulation 1998} & $\begin{array}{l}\text {-Prohibits a drinking water supplier from doing any work or } \\
\text { constructing any structure which will pollute the source of the water } \\
\text { resource or have a substantial adverse impact on the environment. }\end{array}$ \\
\hline & -Deals with the licensing of use drinking water \\
\hline & -The penalty of up to NRs. 10,000 on pollution of drinking water \\
\hline \multirow[t]{2}{*}{ The Local Self Governance Act 1999} & $\begin{array}{l}\text {-Water and sanitation system and solid waste management authority } \\
\text { provide to local bodies }\end{array}$ \\
\hline & $\begin{array}{l}\text {-Impose a punishment to NRs.15000, dumping of solid waste in a water } \\
\text { body }\end{array}$ \\
\hline $\begin{array}{l}\text { Water Supply and Sanitation Sector policy for Kathmandu Valley } \\
\qquad 2000\end{array}$ & $\begin{array}{l}\text {-KUKL established to operate and manage water supply in Kathmandu } \\
\text { Valley }\end{array}$ \\
\hline NDWQS 2006 & $\begin{array}{l}\text {-NDWQS provisions to improve water quality in urban and rural water } \\
\text { supplies }\end{array}$ \\
\hline \multirow[t]{2}{*}{ Water Supply Management Board Act, 2006} & -Prevents misuse and pollution of potable water \\
\hline & -Fine on contaminating potable water up to NRs. 25000 \\
\hline The Constitution of the Kingdom of Nepal 2015 & -Basic needs policies and clean environment rights of the citizen \\
\hline
\end{tabular}

\section{Conclusion and Recommendation}

Economy, commerce, education, medical facilities, governance and other productive activities concentrated only in Kathmandu Valley are ground of swift urban growth with no national urbanization policy. The dearth of strong policies and supervision and freedom to migrate has become main reasons to exploit the environment emerging adverse self-health effects. Kathmandu Valley primarily faces health challenges, compound effects of Air and Water pollution. The proliferation of automobiles, the operation of additional diesel transportation, brick-kiln factories which is the dominant source of air pollutant and loosely a decade-long road expansion and pipe laying project still in halfway are surplus. Beyond, bowl-shaped the topography of Kathmandu Valley is innately vulnerable to air pollution [14]. The unmatchable ratio of population, and quantity of water, people of valley extremely depend on groundwater. Bacteriological contamination in most groundwater has contributed to the rise of water-borne diseases. Valley is also at risk from toxic pollution by discharge of untreated sewage, industrial waste and improper management of solid waste and other various human activities. Awareness of pollution on public health, encouraging the use of the biodegradable-recycle product, effective legislation, safe chemical management law, training framers to handle fertilizer and appropriate land use planning is necessary to improve water quality in Kathmandu Valley [77]. Nevertheless, ongoing MWSP is the big hope for Kathmandu Valley to meet long-term clean water, probably no need to search down deep groundwater $[4,61]$.

The road being solo transportation medium; traffic, including emissions and dust associated with traffic, is a most potential threat; winter months being most helpless in Kathmandu Valley. Mass transit buses, monorail, tram, BRT system can be alternative passenger vehicles to encourage people to use public transportation and discourage the use of private vehicles 
to reduce air pollutants [77]. However, disallowing densely polluted brick kiln factories, import of 2-stroke engines, banned on 20-year-old cabs, subtraction of three wheels diesel vehicle and promotion of EVs are few measures undertaken by the government were laudable to enhance air quality [77]. The street along the pleasant pedestrian walkway, safe-convenient routes to reach the destination with adequate cycle infrastructure, can be a good alternative to switch from motor vehicle to bicycle. Not only vehicle-centric transportation, people-centric transportations are needed to promote sustainable development. Legislation and policies limited to documentation; implementation and strict monitoring of applied strategy from an administrative level, local authorities and individual self-conscious may support to create sustainable and healthy urban environment.

\section{Refernces}

1. M Moore, P Gould and B S Keary (2003) Global urbanization and impact on health. Int J Hyg Environ Health 206(4-5): 269-278.

2. (2014) World Urbanization Prospects The 2004 Revision Highlights. United Nations p. 32.

3. (2007) World Urbanization Prospects The 2007 Revision Highlights. United Nations 2(4): 883.

4. (2006) Asian Development Bank/ICIMOD, Environment Assessment of Nepal: Emerging Issues and Challenges. Kathmandu, Nepal.

5. RB Thapa, Y Murayama, S Ale (2008) City Profile: Kathmandu. Cities 25(1): 45-57.

6. H Gurung (1989) Regional Patterns of Migration in Nepal 5(1).

7. J Wahba (1996) Urbanisation and Migration in the Third World. Reprod from Econ Rev 14(2).

8. E Muzzini, G Aparicio (2013) Urban growth and spatial transition in Nepal: an initial assessment. Washington, DC: World Bank, USA.

9. (2018) Nepal Population-Worldometers.

10. (2016) CBS Central Bureau of Statistic. Population of Nepal (Selected Data - Central Development Region). His Majesty's Government of Nepal, Kathmandu, Nepal.

11. PK Pradhan (2004) Population Growth, Migration and Urbanisation: Environmental Consequences in Kathmandu Valley, Nepal. Environ Chang Its Implic Popul Migr pp. 177-199.

12. SM Pradhan (1988) Kathmandu: metropolitan development and conservation issues. Reg Dev Dialogue 9(3): 203-21.

13. BA Portnov, M Adhikari, and M Schwartz (2007) Urban Growth in Nepal : Does Location Matter? Urban Stud 44(5-6): 915-937.

14. (2017) MoPE Air Quality Management Action Plan for Kathmandu Valley. Government of Nepal.

15. A de Sherbinin, A Schiller, A Pulsipher (2007) The vulnerability of global cities to climate hazards. Environ Urban 19(1): 39-64.

16. RB Thapa and Y Murayama (2009) Spatial structure of land use dynamics in kathmandu valley. pp. 11-16.

17. Guna, R Bhatta (2014) Structural Change and Per Capita Income in Nepal: Empirical Evidences. NRB Econ Rev 26(2): 41-60.

18. (2011) CBS, “Nepal living standards survey," Kathmandu: His Majesty's. Government of Nepal.

19. S Bakrania (2015) Urban poverty in Nepal-GSDRC Helpdesk Research Report. Birmingham UK: GSDRC.
20. (2018) UNISDR Prevention Web.

21. ME Northridge, E Sclar (2003) A Joint Urban Planning and Public Health Framework: Contributions to Health Impact Assessment. Am J Public Heal 93(1):118-121.

22. R Godfrey, M Julien (2005) Urbanisation and health. Clin Med (Northfield II) 5(2): 137-141.

23. KM Shakya, RE Peltier, H Shrestha, RM Byanju (2017) Measurements of TSP, $\mathrm{PM}_{10}, \mathrm{PM}_{2.5}, \mathrm{BC}$, and PM chemical composition from an urban residential location in Nepal. Atmos Pollut Res 8(6): 1123-1131.

24. (2009) NHRC \& WHO Situation analysis of environmental health in Nepal 2009.

25. V Mody, SD Ray (2014) The National Institute of Environmental Health Sciences. Encycl Toxicol pp. 456-457.

26. H J Jahn, A Schneider, S Breitner, M Wendisch, A Krämer, et al. (2011) Particulate matter pollution in the megacities of the Pearl River Delta, China - A systematic literature review and health risk assessment. Int J Hyg Environ Health 214(4): 281-295.

27. (2018) Dylos Corporation, What is Particulate Matter?

28. (2016) WHO Ambient air pollution: A global assessment of exposure and burden of disease.

29. (2018) WHO Ambient (outdoor) air quality and health. World Health Organization.

30. K Shrestha, PP Shrestha, Geeta Shrestha (2017) Carbon Dioxide Emissions by the Transportation Sector and Its Impact on Health in the Kathmandu Valley, Nepal. J Civ Eng Archit 11(2): 184-193.

31. (2003) CEN \& ENPHO Health Impacts of Kathmandu's Air Pollution.

32. (2006) WHO Air quality guidelines for particulate matter, ozone, nitrogen dioxide and sulfur dioxide: Global update 2005 (Summary of risk assessment). World Heal Organ.

33. AK Pokhrel, Michael N Bates, Jiwan Acharya, Palle Valentiner-Branth, Ram K Chandyo, et al. (2015) $\mathrm{PM}_{2.5}$ in household kitchens of Bhaktapur, Nepal, using four different cooking fuels. Atmos Environ 113: 159-168.

34. O P Kurmi, Semple S, Devereux GS, Gaihre S, Lam KB, et al. (2014) The effect of exposure to biomass smoke on respiratory symptoms in adult rural and urban Nepalese populations. Environ Heal A Glob Access Sci Source 13(92).

35. BM Kim, JS Park, SW Kim, SC Yoon, HJ Jeon, et al. (2015) Source apportionment of $\mathrm{PM}_{10}$ mass and particulate carbon in the Kathmandu Valley, Nepal. Atmos Environ 123: 190-199.

36. P Khanal, A Gurung, PB (2017) Chand Road Expansion and Urban Highways : Consequences Outweigh Benefits in Kathmandu. J Assoc Nepal Himal Stud 37(1).

37. (2016) Five years on, just 26\% expansion work completed in Valley. My Republica pp. 1-11.

38. (2016) Only $34 \mathrm{~km}$ roads expanded in nine years. The Himalayan Times.

39. (2018) The Melamchi Mess. My Republica.

40. P Gautam, U Blaha, E Appel, N Ghanashyam (2004) Environmental magnetic approach towards the quantification of pollution in Kathmandu urban area, Nepal. Phys Chem Earth 29(13-14): 973-984.

41.SM Thygerson, S Sanjel, S Johnson (2016) Occupational and Environmental Health Hazards in the Brick Manufacturing Industry in Kathmandu Valley, Nepal. Occup Med Heal Aff 4(5).

42. (2015) NHRC Situation Analysis of Ambient Air Pollution and Respiratory Health Effects in Kathmandu Valley, Nepal. 
43. K Simkhada, K Murthy V, SN Khanal (2005) Assessment of ambient air quality in Bishnumati corridor, Kathmandu metropolis. Int J Environ Sci Technol 2(3): 217-222.

44. O Kurmi, PR Regmi, PR Pant (2016) Implication of Air pollution on health effects in Nepal: Lessons from global research. Nepal J Epidemiol 6(1): 525-527.

45. C K Sharma (1997) Short Communication: Urban air quality of Kathmandu Valley, Kingdom of Nepal. Atmos Environ 31(17): 28772883.

46. (2018) Environmental Performance Index: Air quality top health threat. Yale University, USA.

47. (2006) CEN Air Quality Status and Management in Kathmandu Valley: Make the City Air Breathable (Maya factSheet \#5). Clean Energy Nepal MaYa Fact.

48. (2017) Topography to blame for worsening air pollution. The Himalayan Times.

49. SK Pariyar, T Das, T Ferdous (2013) Environment And Health Impact For Brick Kilns In Kathmandu Valley. Int J Sci Technol Res 2(5): 184187.

50. (2017) European Uniion Air Quality Standards.

51. (1997) The World Bank, Urban Air Quality Management Strategy in Asia: Kathmandu Valley Report. 13(3).

52. (1997) CWIN Tempo Khalassi Baal Sramikharuko Shthiti. Kathmandu, Nepal.

53. (2001) NESS WHO / PoA No. NEP PHE 001. Result no. 8. Kathmandu, Nepal, Heal Res Counc.

54. (2006) ADB and CAI-Asia Center Country Synthesis Report on Urban Air Quality Management. Asian Dev Bank.

55. (2004) NHRC \& WHO Situation Analysis of Indoor Air Pollution and Development of Guidelines of Indoor Air quality Assessment and House Building for Health. Kathmandu, Nepal.

56. (2006) NHRC \& WHO Development of Procedures and Assessment of Environment Burden of Disesse of Local levels due to major Environment Risk factors. Res Report Kathmandu.

57. A Gurung (2016) Understanding Air Pollution and Human Health Burden Associated in Kathmandu Valley.

58. SR Shrestha, NT Kim Oanh, Q Xu, M Rupakheti, MG Lawrence (2013) Analysis of the vehicle fleet in the kathmandu valley for estimation ofenvironment and climate co-benefits of technology intrusions. Atmos Environ 81: 579-590.

59. V Bhatt (2013) Estimation of Amount of $\mathrm{CO}_{2}$ Reduction by Safa Tempo (Electric-Three Wheelers) in Kathmandu Valley.

60. NR Warner, J Levy, K Harpp (2008) Drinking water quality in Nepal's Kathmandu Valley: A survey and assessment of selected controlling site characteristics. Hydrogeol J 16(2): 321-334.
61. P Udmale, H Ishidaira, B Thapa, N Shakya (2016) The Status of Domestic Water Demand: Supply Deficit in the Kathmandu Valley, Nepal. Water 8(5): 196.

62. A Ishtiaque, M Shrestha, N Chhetri (2017) Rapid Urban Growth in the Kathmandu Valley, Nepal: Monitoring Land Use Land Cover Dynamics of a Himalayan City with Landsat Imageries. Environments 4(4): 72.

63. S Shrestha, DJ Semkuyu, VP Pandey (2016) Assessment of groundwater vulnerability and risk to pollution in Kathmandu Valley, Nepal. Sci Total Environ 556: 23-35.

64. A Dixit and M Upadhya (2005) Augmenting groundwater in Kathmandu Valley: challenges and possibilities. Nepal water Conserv Found Kathmandu, Nepal.

65. BR Pant (2011) Ground water quality in the Kathmandu valley of Nepal. Environ Monit Assess 178(1-4): 477-485.

66. T Prasai, B Lekhak, DR Joshi, MP Baral (2007) Microbiological Analysis of Drinking Water of Kathmandu Valley. World Health 5(5): 112-114.

67. (2014) DoHS Annual Report Kathmandu, Nepal.

68. S Shrestha, Y Aihara, K Yoden, Z Yamagata, K Nishida, et al. (2013) Access to improved water and its relationship with diarrhoea in Kathmandu Valley, Nepal: A cross-sectional study. BMJ Open 3(6): 1-8.

69. S Shrestha, E Haramoto, R Malla, K Nishida (2015) Risk of diarrhoea from shallow groundwater contaminated with enteropathogens in the Kathmandu Valley, Nepal. J Water Health 13(1): 259-269.

70. (2009) DoHS Annual Report. Kathmandu, Nepal.

71. D Dinesh C, W Kunio (2005) Impact of solid waste on water quality of Bishnumati River. J Nepal Geol Soc 31: 19-24.

72. SM Shrestha, K Rijal, MR Pokhrel (2016) Assessment of Heavy Metals in Deep Groundwater Resources of the Kathmandu. J Environ Prot (Irvine Calif) 7(4): 516-531.

73. S Khani, B Khani, G Sikpasor (2001) Groundwater Quality: Nepal. Nat Environ Res Counc pp.1-4.

74. M Jaishankar, TTseten, N Anbalagan, BB Mathew, KN Beeregowda (2014) Toxicity, mechanism and health effects of some heavy metals $7(2): 60-72$.

75. S Martin, W Griswold (2009) Human health effects of heavy metals. Environ Sci Technol Briefs Citizens 15: 1-6.

76. Wateraid (2005) Water Laws in Nepal. pp. 1-94.

77. T Kjellstrom, M Lodh, T Mcmichael, R Shrestha, S Kingsland (2006) Air and Water Pollution : Burden and Strategies for Control. Air Water Pollut pp. 817-832. 
This work is licensed under Creative Commons Attribution 4.0 License DOI: 10.19080/JOJPH.2018.03.555617

\section{Your next submission with Juniper Publishers} will reach you the below assets

- Quality Editorial service

- Swift Peer Review

- Reprints availability

- E-prints Service

- Manuscript Podcast for convenient understanding

- Global attainment for your research

- Manuscript accessibility in different formats ( Pdf, E-pub, Full Text, Audio)

- Unceasing customer service

Track the below URL for one-step submission https://juniperpublishers.com/online-submission.php 